\title{
National Parks, coffee and NTFPs: the livelihood capabilities of Adivasis in Kodagu, India
}

\author{
Shrinidhi Ambinakudige ${ }^{1}$ \\ Mississippi State University, USA
}

\section{Introduction}

Poovamma faces another day without paid work. Normally, at this time of year she would be working in the lower valley weeding coffee plantations, but that employment has dried up since the crash in global coffee prices. Years ago, she might have gathered medicinal herbs and green manure in the surrounding forests, but available forest areas are becoming scarce, and park rangers restrict those activities in the remaining forested areas. Her husband, fortunately, is working for one of their patrons this week, pruning shade trees in coffee orchards: men generally do the pruning. Poovamma has been waiting for rain for several weeks now. Once it rains she can get work in the local rice paddy farm, since rice farmers prefer women laborers to transplant rice plants. Tomorrow, she will go to another farm where ginger is cultivated in rice paddies to offset the decline in coffee prices. She decides to spend the morning clearing bushes around the family's house. Since she does not have ownership title on this land inside the boundaries of the National Park, this is a task best done little by little, so as not to attract attention from Park guards. In the afternoon, she goes to a site outside the Park where the village Panchayat (government) is building a kindergarten for children in the tribal area. The Panchayat initiated this project because of Poovamma's persistent efforts as a member of the Panchayat. While returning from the project site, she will bring a head-load of dead and dried twigs for cooking and heating water. She collects firewood during the evening to avoid harassment by forest guards.

As in the rest of the world, environmental change is transforming this little tribal area in Kodagu, India where Poovamma makes her living. The transformations of forest to coffee plantation, forest to national parks, and rice paddies to ginger farms bring with them transformations in local livelihood possibilities. Institutional factors ranging from the family structure to village politics to forest policies to global trade agreements shape people's livelihood outcomes. As a social actor, Poovamma has various roles ranging from head of household to tribal woman to member of the local Panchayat. Each of these roles brings different livelihood possibilities and different environmental changes. Any inquiry into conservation and livelihood should address these relations among livelihood possibilities, environmental change, and institutional complexities.

Indigenous communities in India are largely referred to as 'Adivasis', meaning original inhabitants. Adivasis like Poovamma in the Kodagu district in Southern India depend on forest resources and agriculture labor to sustain their livelihood. These two major livelihood sources have undergone changes over the years (Ambinakudige 2006). Aggressive conservation policies of the state and creation of Protected Areas have generally restricted Adivasis access to resources and pushed them to market economy (Langton 2005; Lele and Shrinidhi 1998). On the other hand, globalization and the commodification of agriculture have created uncertainties in the livelihood capabilities of Adivasis (Bawa et.al. 2007). Therefore, it is imperative to explore which institutional factors shape Adivasis' livelihood capabilities; how do those institutional factors operate at various scales? How do Adivasis cope with marginalization resulting from conservation policies, and the vagaries of the market economy? To answer these questions, this paper analyzes Adivasis' livelihood capabilities amidst conservation policies, the market economy, and various other institutional factors operating at global, regional, and local scales.

\section{Indigenous communities, livelihoods, and Protected Areas}

Blaikie et.al. (1994) define 'livelihood' as the command an individual, family or other social group has over an income and/or other bundles of resources that can be used or exchanged to satisfy its needs. Therefore, livelihood can refer to the activities of an individual, a family, or a social group. The central concept in the definition of livelihood is "resources and the command over those resources." Rural livelihoods also comprise "diverse portfolios of activities and social support capabilities for survival and to improve their standard of living" (Ellis 1998). These livelihood strategies and outcomes are structured by institutional and vulnerability factors (Ruben 2003). Vulnerability factors include the shocks and stresses that people cope with in their livelihood struggles (De Haan 2000).

Definition of an institution is complex, and in the academic literature, definitions turn on the theoretical interest and the pragmatics of a research project. According to Crawford and Ostrom (1995),

\footnotetext{
${ }^{1}$ Assistant Professor, Department of Geosciences, Mississippi State University, 355 Lee Blvd, Mississippi State, MS 39762, USA. Email: ssa60 "at" msstate.edu. I would like to thank Prof. Dan Klooster for his guidance and support for this study. I also would like to thank two anonymous reviewers for suggestions and comments. Any errors and shortcomings in this paper are my sole responsibility.
} 
institutions are enduring regularities of human action in situations structured by rules, norms, and shared strategies, as well as by the physical world. These rules, norms, and shared strategies are constituted and reconstituted by human interactions in frequently occurring or repetitive situations (Crawford and Ostrom 1995). Institutional factors that influence livelihood outcomes include policies, legislation, customary laws, the organizational structure and social norms (Ambinakudige 2006). These factors determine which livelihood strategies are open and attractive (Carney 1999). These "transforming structures and processes" operate at various levels of society - from family and village, up to the international level of global political and market institutions (Ruben 2003).

Organizations, for example NGOs and associations, come into existence and evolve through the influence of the institutional structure. In turn, they influence how institutions evolve (Crawford and Ostrom 1995). Therefore, institutional factors in this study include the existence, evolution, and de facto functioning of organizations, policies, legislation, customary laws, and social norms (Ambinakudige 2006). These factors determine what livelihood strategies are open and attractive (Carney 1999). Analysis of livelihood outcomes, therefore, requires sensitivity to resources, the process of converting them to needed goods and services, and the dynamics of change and social vulnerability to change.

The livelihood outcomes of Adivasis and other indigenous peoples are particularly influenced by the institutions and organizations of nature conservation. A conservation policy that distresses people that are less powerful, politically marginalized, and poor, has failed in its goal (Agrawal and Redford, 2009). Unfortunately, most conservation strategies involving the protection of habitats and species through the demarcation of Protected Areas also elevate levels of distress for poor people living in and around them by foreclosing access. For indigenous forest dwellers, nature and livelihood are not separate concepts. The Gimi community in Papua New Guinea for example, does not acknowledge a separation between nature or culture, so Western 'nature conservation' is alien to them and contemporary conservation strategies often fail to recognize this (West and Brockington 2006). Although, their cultural conditions are compatible with contemporary conservation principles (i.e., low settlement densities, limited technology, and largely subsistence production), Adivasis were generally kept away from conservation projects (Holt 2005). Worse, establishing a Protected Area can alienate the land-use rights of native people (Agrawal and Ostrom 2001). Repeatedly, Protected Areas have been shown to restrict rural people's access and use of resources through legislation, enforcement, and some privatization (Greenough 2003). As a result, land-use practices such as gathering wood and hunting can become criminalized (Klooster 2000; Freedman 2002). In addition, Protected Areas involving new economic activities such as park and wildlife tourism create a different scenario where indigenous people find it harder to pursue lifestyles that are more 'traditional'. If they do not want to take part in the new economic activities of a new Protected Area, they find survival difficult, as their subsistence options are limited because of resource-management regulations (Weber 1991). Conservation projects that provide positive benefits to local people from natural resources can enable sustainable management over the long term. Conversely, negative social impacts make conservation more difficult and less sustainable (Bray and Velazquez 2009).

Many Indigenous peoples occupy the territories claimed by Protected Areas. Conservation strategies cannot ignore the livelihoods of the large number of poor, powerless people still living in these areas and potentially threatened by eviction. Occupancy rates are hard to estimate - perhaps 56\%-72\% in India (Kothari et al. 1989) and as high as 85\% in South America (Amend and Amend 1995). Adivasi and indigenous livelihood disruption resulting from restriction of access to Protected Areas is complex, and solutions have proven elusive (Sato 2000). Protected Areas potentially expose Adivasis to new, unfamiliar livelihood options such as waged work in the commercial farming sector (usually situated just outside the Protected Area), but this makes them vulnerable to market volatility (Ambinakudige 2006). Over time, commodification of agriculture and thereby market dependency has brought about a structural change in peasant livelihood processes in the form of rising cost of production, increased in- and out-migration, and dependency on export crops (Watts 1983; Bernstein 1994). As livelihoods become more vulnerable to market failure and rising costs of land without guarantees of higher output, the livelihoods of the laborers depending on those farms will also become vulnerable to market volatility.

The livelihoods of Adivasis in the study area are not just determined by local institutions. Complex forces, including the global nature of conservation politics, the globalization of local economies and commodification of agriculture all impact on the livelihoods of Adivasis. There is a need to understand this complexity much better, to help protect human rights and to conserve natural resources.

\section{Background and the study area}

This study was conducted in the Kodagu district of Karnataka State in Southern India (Fig. 1). Here, forest and coffee farms are the two main sources of livelihoods. Kodagu is one of the major coffee growing regions in India. Large areas of forest in Kodagu have been converted to shade-grown coffee cultivation in the last century (Menon and Bawa, 1998; Shrinidhi and Lele 2001; Ambinakudige and Sathish 2009).

In Kodagu, rice is traditionally grown for subsistence. Coffee, black pepper, cardamom, oranges and ginger are the other regional commercial crops. Of these crops, coffee has played a major role in the 
socioeconomic development of Kodagu. Adivasis living in the forests of Kodagu have been the major labor source for the Kodagu farmers (Ambinakudige 2006). Today, forests cover about 36\% of the land in Kodagu, a drastic reduction from $88 \%$ in 1920 . About $71 \%$ of this forest loss is due to coffee cultivation (Menon and Bawa 1998).

The forests of Kodagu are known for their rich flora and fauna. The Nagarahole National Park, which covers an area of about 643 sq.km., is one of the several Protected Areas in the region (Appayya 1999; Mahanty 2003). This forest is primarily deciduous with patches of tropical semi-evergreen vegetation. Nagarahole forest is also very rich in fauna including tigers, leopards, and elephant. In 1973, Project Tiger was launched in Nagarahole forest to protect tigers whose numbers had shrunk from an estimated 40,000 at the turn of the century to 1,827 in 1972 (Government of India 1983). The forests of Nagarahole are also home to hundreds of Adivasis. The Kurubas and the Yaravas are the two major Adivasi communities living inside the Park boundaries.

The Kodavas are the major farming community in Kodagu. The Kurubas and the Yaravas depend on waged labor in coffee farms and forest products for their livelihoods. There are two subgroups of Kurubas. The Jenu Kurubas are primarily hunter-gatherers who are expert honey gatherers; they also work as casual laborers in the local coffee farms. The Betta Kurubas (hill dwellers) are food gatherers who specialize in bamboo craft. The Yaravas specialize in fishing and subsistence agriculture (Richter 1870, Singh 1994, Mahanty 2003). Today, many Yaravas depend on coffee waged labor as their main livelihood activity. According to a survey conducted by the District Commissioner's office in Madikeri, Kodagu in 2004, there are 155 tribal settlements in Kodagu. Of the three talukas (sub-districts) in Kodagu, the Virajpet taluk where Nagarahole Park is situated, has the majority of the Adivasi settlements in the District.

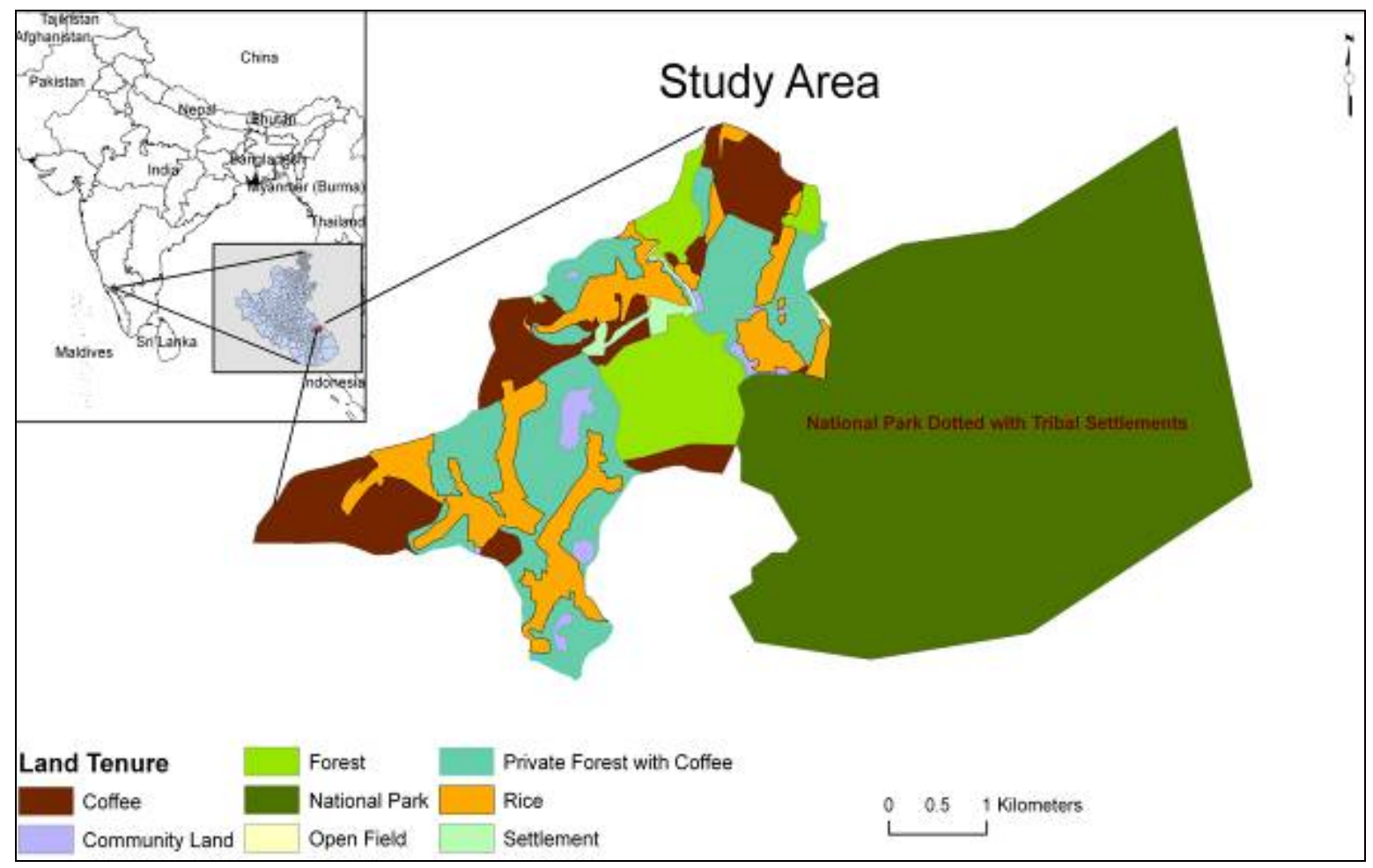

Fig. 1: The study area in Kodagu. Tribal settlements exist within the National Park.

\section{Methods}

To understand how Adivasis' livelihood capabilities are shaped in Kodagu, field interviews and an archival study of coffee cultivation and forest policies in the region was carried out in the summer of 2004. Archival data were collected from the Kodagu District record room, the Karnataka state archive in Bangalore, and historical records of meeting minutes of the Coorg Planter's Association in Kodagu. In addition, semi-structured interviews of 50 Adivasi were conducted to collect details on the role of forest policies, coffee market, and the local sociopolitical power structure on Adivasis' livelihoods. Open-ended questions were used in the interviews. Among the 50 participants, 32 were Kurubas and 18 were Yaravas. 
The sampling method used in this study was purposive; a most commonly used method in qualitative research. The sample sizes are determined based on 'theoretical saturation'. Theoretical saturation is the point in data collection when new data no longer bring additional information to the research questions (Holloway 1997).

Five knowledgeable, non-Adivasi individuals in the study area were also interviewed. They had lived in the area for a long time and are familiar with the local culture and society. The study used snowballsampling (Holloway 1997), where knowledgeable individuals were identified from the participants who had already been interviewed. Other organizations - the Large Scale Adivasis Multipurpose Society (LAMPS), the local co-operative bank, the commercial bank, the village office, Forest Department officials and the local coffee trader were also visited and interviewed. In particular, interviews sought to distil more information about institutional factors in areas such as de facto forest policies, the local coffee labor market and de facto NTFP (non-timber forest products) collection policies and practices. The power relations, class conflicts, episodes of resistance, and stories of livelihood struggles can be better understood through a narrative approach. The narrative approach allows actors to be observed and asked to narrate various incidents instrumental for sustaining livelihoods (Glaser and Strauss 1967). These conversations took up to four hours. In the case of interviews with Adivasis, conversations were sometimes with an individual member and sometimes with a group of people. Both male and female members of the society were interviewed for their personal insights. All the interviews were recorded, translated, and transcribed. Data were then coded and analyzed manually and with QSR N6 qualitative data analysis software. ${ }^{2}$

\section{Livelihoods of Adivasis in the pre-colonial and colonial periods}

The Adivasis of the Nagarahole forests were mainly hunter-gatherers, pastoralists, and shifting cultivators (Richter 1870). Prior to 1834 the Nagarahole forest was a Royal Hunting Reserve under the control of the local kings. The kings employed Adivasis to catch and tame wild elephants in this forest. After Kodagu was annexed by the British in 1834, they used Adivasis as laborers in logging and other forest operations. This continued in the post-independence period (Rangarajan 1996; Mahanty 2003). During the pre-colonial era, livelihoods depended upon shifting cultivation, hunting and gathering, honoraria from the kingdom for catching elephants, and to some extent, returns from agricultural waged labor in the farms adjacent to the Nagarahole forests. Therefore the local kingdom and its policies, and local customs, were the major institutional factors that were instrumental to Adivasi livelihood outcomes.

Between 1894 and 1901 the British government declared the Nagarahole forests to be "reserved forest". This had a major impact on forest dwellers because "reserved forest" meant shifting cultivation practices were banned. The British also banned resource use by forest dwellers and neighboring villagers (Brand 1933; Mahanty 2003). However, rights of way, collection of NTFPs after obtaining a license (Tireman 1914; Mahanty 2003), and seasonal grazing were permitted (Brand 1933; Mahanty 2003). The British government cleared large areas of the Nagarahole forest and planted it with teak trees. The British regime then hired Adivasis to work in the teak plantation and allowed them to plant food crops such as millet in the forest (Mahanty 2003). Once the teak plants reached a certain age, Adivasis' privileges were curtailed. When cultivation was made illegal, Adivasis were forced to depend more on waged labor in neighboring farms. As a result, Adivasis entered into the cash economy and also began depending on the sale of NTFPs. As the government continued to claim more areas of forest, Adivasis' NTFP-dependent livelihood outcomes also suffered. This forced many of them into waged labor, and sometime bonded labor, in colonial timber operations, on coffee plantations, and on other farms (Janara Budakattu Hakku Stapana Samithi 2000; Ambinakudige 2006). During the colonial period, therefore, Adivasis depended on the livelihoods derived from hunting and gathering, small-scale agriculture and waged labor in the forest plantations and coffee farms.

However, the data on the livelihood conditions of the Adivasis in the pre-colonial period are limited; and therefore it is difficult to analyze the livelihood conditions during this period. Nevertheless, we do know that rights and access to resources in Reserved Forests, land use change policies in the Nagarahole forests, policies to allow cultivation of food crops, and later restriction of cultivation have all acted as institutional factors that affected the livelihoods of the Adivasis. Use restrictions led to the exploration of new livelihood options, including waged labor in the emerging coffee plantations.

\footnotetext{
2 The following steps were involved in qualitative data analysis: 1) Memoing: recording reflective notes about what was learned in each interview and each observation in the field. 2) Data entry: transcribing the interviews and observation data. 3) Coding: careful reading of transcribed data, and dividing the data into meaningful analytical units. When a meaningful unit was recognized (for example, "we do not find work in coffee farms"), they were coded i.e., marking the segments of data with descriptive words, or category names. A master list of codes was maintained thought out the process. Codes were then grouped into meaningful categories.
} 


\section{Livelihoods of Adivasis during the postcolonial period}

In the postcolonial period, there was a paradigm shift in the region's forest policy. After the Nagarahole forest was declared a wildlife sanctuary in 1955, the management regime changed from 'production' forestry to 'protection' forestry (Mahanty 2003). In the 1970s, the Nagarahole forest was declared a National Park under the Wildlife (Protection) Act of 1972. In 1973, Project Tiger was launched in the Nagarahole forest to develop it as a tiger reserve (Government of India 1983). During the process of acquiring the land for the National Park, only recorded (written) rights to land and assets were considered; Adivasis' informal rights and privileges on the land were completely ignored. Furthermore, public interest litigation by the World Wildlife Fund, India seeking the complete implementation of the Wildlife Protection Act of 1972, and the court orders resulting from this, forced many Adivasis to move out of the National Park entirely. Some did remain in the Park (Mahanty, 2003; Ambinakudige 2006). The narrow recognition of property rights inside the Park area during its creation was, therefore, a major institutional factor that affected Adivasis' ability to use natural resources) to sustain their livelihoods (e.g. for fuelwood collection, hunting, house repairs).

The Indian national forest policy of 1988 was a modification of National Parks legislation. It reidentified the need to conserve and preserve biodiversity, but also signaled the intrinsic relationship of the local communities to their forests (Ambinakudige 2006). The policy also identified the protection of customary rights and recognized the importance of forests as a means of livelihood for indigenous peoples. With this new forest policy in place, and under pressure from human rights groups, forced evictions of people from the National Park were halted. But this measure did not improve the living conditions of the Adivasis. Although, the government no longer forced Adivasis to evacuate the Park, it did not make any effort to involve them its management decisions. Consequently, the Forest Department is still making their life difficult by restricting their activities inside the Park.

According to a World Bank report (1996), increasing government protection and legal control have curtailed local communities' resource use and management, forced changes in traditional livelihoods, and removed incentives to use resources sustainably. Employment opportunities in the Forest Department have also shrunk with the establishment of the National Park. While the new forest policy and support from human rights groups acted as stimulants to protect tribal rights, they have failed to improve the living conditions of the Adivasis. Adivasis, meanwhile, developed two main types of livelihood activities: NTFP collection and waged labor in coffee farms. The third livelihood option is to work for the Forest Department. This includes capturing and taming wild elephants, containing wildfires, clearing roads, digging trenches and reforestation programs.

The rules and regulations in the National Park have restricted Adivasis' chances of improving their livelihood capabilities, despite the 1988 amendments. Consequently, Adivasis cannot venture too deeply into the forest to collect basic necessities, such as fuelwood; they cannot cultivate food crops inside the forest; and they cannot rear livestock or keep dogs as pets because it might spread contagious diseases to wildlife. Adivasis are not allowed to hunt, even for ritual hunts. Furthermore, simple repairs to their houses are not permitted. Building new infrastructure, including digging wells or de-silting tanks, is prohibited. There is a total ban on collection of NTFPs such as tubers, mushrooms and other wild vegetables and fruits, which constitute a major part of the Adivasis' diet. Their traditional music and dances are also forbidden inside the National Park as the noise might affect the wild animals. Items of basic need, which the Adivasis used to get from the forest, must be purchased from the market. The situation is more difficult when a family expands through childbirth or marriage; Adivasis cannot construct new houses for family members. They live in constant fear of the Forest Department, and wild animals. The creation of the National Park was the initial event that led to the lack of infrastructure and basic facilities for the Adivasis. As a result, Adivasi also lag behind in their socioeconomic development, given the sanctions imposed on their activities inside the Park boundaries, and their children are missing many opportunities.

\section{The role of NTFP in Adivasis' livelihood capabilities}

Intensive fieldwork in the study area included interviews with Adivasi, officials of the NTFP cooperatives, and other knowledgeable individuals within and outside the Nagarahole National Park. The collection and sale of non-timber forest products such as honey, soap nuts, lichen and tree gum have always been a subsidiary occupation for Adivasis. Currently, they are not permitted to collect any of these NTFPs inside the Park. They are, however, free to collect NTFPs in the forests lying outside its boundaries. After independence from Britain, the government of India adopted the recommendations of the Bawa Committee of 1971 and introduced the concept of the Large-scale Adivasi Multi-Purpose Society (LAMPS) Ambinakudige 2006). The LAMPSs were to be cooperative societies for integrated tribal development, with local socio-economic development achieved through marketing of NTFPs, provision of credit, agricultural inputs, and rationed supply of groceries (Bawa et.al., 2007; Lele \& Rao 1996).

One of these LAMPS was established in Kodagu. The Karnataka Forest Department leases certain forest areas to the LAMPS for collecting NTFPs. Protected Areas, such as National Parks and wildlife sanctuaries, are excluded in the leases. Before the start of the NTFP collection season, the LAMPS 
announces the "collector price," which is the fee per kilogram of each item paid by LAMPS to collectors. The LAMPS later auctions off the entire quantity of honey, soap nuts or other NTFP to the highest bidder. Any profits are supposed to be returned to all members through dividend payments (Ambinakudige 2006).

In the study area, the LAMP society is located in Thithimathi village in South Kodagu. Interviews with tribal members and LAMPS officials showed how the organisation influences Adivasi livelihoods. There are 4,350 tribal members. According to the secretary of the LAMPS, an individual tribal member could make up to Rs. 200 per day (US \$4.45) by collecting and selling NTFPs to the LAMPS, which is much more profitable than working in the coffee plantations. ${ }^{3}$ Although the NTFPs are seasonal, people are able to collect one or another product throughout the year. April to June is the honey season. June- December is the season for collecting lichen; December to March is the time to collect segekai (Acacia Concinna, for shampoo), gooseberries (Phyllanthus Emblica) and soap nuts (Sopindus emerginatus). Some tribal members depend solely on the collection of NTFPs throughout the year; they collect them from the forests outside the National Park. The LAMPS paid Rs. 55 per kg. of honey and Rs. 50 per kg. of lichen in 2004. Although the LAMPS was created to help Adivasis, it also buys NTFPs from non-Adivasis. The latter purchase NTFPs from the Adivasis and sell them to the LAMPS: these people are locally called "agents". When Adivasis are in need of immediate cash, they sell the NTFPs to the nearest and most easily accessible agents.

Interviews with the Adivasis living inside the National Park indicated that some often clandestinely collect NTFPs, especially honey, within the Park's boundaries. Forest officials often confiscate their tools if they are caught collecting or taking fuelwood inside the Park. Studies of Protected Areas and peasant and tribal livelihoods have argued that the state's policies generally fail to address the structures of rural poverty that perpetuate "criminal" acts against the forest by villagers (Peluso 1992; Bryant 1997; Klooster 2000). Peluso (1992) argued that the state's cultural control, and peasant's cultural resistance, results in social tension and environmental degradation. While some Adivasi families in Nagarahole National Park accepted the government's rehabilitation program, and settled in a new location outside the Park to initiate sedentary agriculture, others refused to leave. The Adivasis resisted pressure from the governmental and environmental groups to leave the Park, fearing the new unknown and the loss of their traditional lifestyle. The 1988 forest policy of the government of India, which recognized the rights of Adivasis, constrained the Forest Department from forcefully evacuating them from the Park. But this did not stop the Forest Department from restricting Adivasis' access to the resources in the Park. Now Adivasis can live inside the Park but cannot use it as they would like to. This new reality led to everyday resistance - Adivasis risk meeting their basic needs through illegal means. Forest guards often ignore certain minor violations such as collection of firewood. But a larger violation will lead to their arrest, or confiscation of their tools by the forest guards "to teach them a lesson". It is not uncommon for forest guards and officials to accept bribes in the form of honey or other forest products from Adivasis. Corruption is an institutionalized (Robbins, 2000). In Nagarahole National Park it influences the workings of Adivasis' livelihoods.

The LAMPS normally sell NTFPs through public auctions; in theory, the state co-operative marketing federation should find the best market for the NTFPs and arrange the auction. In the study area, however, the LAMPS sells the NTFPs that are collected in small quantities directly to the traders. This happens because there is a lack of storage at the local LAMPS, and the marketing federation has been ineffective in marketing the NTFPs. The current arrangement lessens the chances of getting competitive prices and opens the possibility of corruption.

The two major institutional factors significantly influencing the NTFP based livelihood options of the Adivasis in Kodagu are, therefore, the de facto forest policies and the functioning of the LAMPS. While the creation of the National Park hindered traditional modes of collecting and exchanging NTFPs, the recognition of Adivasi rights over the NTFPs outside the Park has been a way to sustain traditional sources of income. The LAMPS, on the other hand, helped the Adivasis by providing price stability for NTFPs and reducing exploitation by private traders. But the LAMPS are inefficient and corrupt, and could be of much great assistance to those they are meant to support.

\section{The role of coffee in Adivasis' livelihood capabilities}

By the time the National Park was created in the 1970s, coffee farming in Kodagu was well established and some Adivasis were already working as laborers on coffee farms. Introduction of coffee on a commercial scale by the European settlers had already increased the demand for agricultural laborers (Richter 1870). Even today, coffee cultivation is little mechanized and it depends on manual labor. Adivasis are the major local workforce. Demand for labor has helped Adivasis to sustain themselves when other livelihood options have failed.

Coffee was one of the most highly regulated commodities in the world, under the International Coffee Agreement (ICA) (Talbot 2004). In India, the Indian Coffee Board has regulated the coffee market since its inception in 1942, with a great degree of state control over sales and pricing. However, due to neoliberal

\footnotetext{
${ }^{3}$ One US dollar was approximately 45 Indian rupees during the study period.
} 
influence on the global coffee market and disagreements among the members regarding sales quotas, the ICA was terminated in 1989. In 1992 the central government amended the Coffee Act (1942) and announced that growers could sell 30\% of their coffee on the open market. In 1994, this was raised to 50\% and in 1996 the coffee market was fully deregulated, and the Coffee Board became an advisory body (Ambinakudige 2006).

The collapse of the ICA and deregulation of the coffee market have filtered through to Kodagu. After the collapse of the ICA, the world coffee market observed a rise in price between 1994 and 1997 . This rise was attributed to the decline in the global coffee supply due to frost damage in Brazil, the major producer (Talbot 2004; Ambinakudige 2009). During this period, with the increased mobility and capital of the coffee growers, investments in coffee farms also increased. This benefited Adivasi workers and they were paid higher wages. As one Adivasi member explained: "When the coffee growers received higher coffee prices, they gave us more work and more money. We demanded higher wages and they just gave us." Coffee farmers even provided Adivasis with transportation facilities to go to work. As another Adivasi said "Coffee growers from far away places came to our colony to take us to their plantations. They drove their vehicles to take us and in the evening they brought us back."

After 1997, coffee prices started declining rapidly in India. This is the period generally referred to as the "coffee crisis". Between 1998 and 2004, the Robusta coffee price fell from 76 cents to 31 cents per pound. The price of Arabica coffee dropped from 99 cents to 58 cents per pound during the same period (Source: International Coffee Organization). This sharp fall had a wide impact on the livelihoods of coffee farmers and workers (Ambinakudige 2006). Investment in coffee farms decreased. Coffee farmers reduced fertilizer application, weeding, and many other cultivation practices and they hired fewer workers. Adivasis were able to get only 2-3 days of work each week.

Social relationships with the farming communities in Kodagu have affected Kurubas and Yaravas differently. Yaravas have always worked in the fields of the local farmers. While Yaravas often bonded to a particular farmer, Kurubas do not like to commit themselves to any particular farmer, and prefer to live more traditionally in the forests. During the coffee crisis, it was the Kurubas that were affected the most as work ceased. For Yaravas, they were better placed to gain what work remained, and there was some assistance in the form of food, shelter, and work from the farmers.

Thus global coffee market fluctuations, and the social relationships with the coffee growers, influence the wages and allowances that Adivasis receive. Global level institutional factors along with local level social factors altered the livelihood capacities of a small tribal community.

\section{Conclusions}

Adivasis' traditional substance practices and their knowledge systems are eroding due to two main factors - the conservation of nature and the commodification of agriculture. Conservation strategies have restricted indigenous people's access to natural resources through imposed land tenure arrangements (Langton et.al. 2005). For conservationists, global biodiversity preservation has taken precedence over the livelihoods needs of Adivasis (Langton 2003). Market forces in a globalized world can upset local food production and the labor market. States like India tend to believe in a modern economic system, but they are also obligated to preserve the rights of indigenous people. This results in new institutional arrangements, but in this case, an unsatisfactory outcome for groups caught between tradition and modernity in and around a National Park. In this context, understanding the livelihood complexities of the poor and powerless, and their coping measures, is an important challenge for political ecologists.

This study identified several institutional factors at various levels that are influencing the process of utilizing NTFPs and other assets, to improve the livelihood capabilities of the Adivasis. Unfortunately, the history of livelihoods presented here illustrates the persistent vulnerability of Adivasis over time. The creation of the National Park negatively influenced almost all aspects of their livelihood activities. The Adivasis' own cooperative (LAMPS) helped preserve their rights to NTFPs, but failed to utilize its full potential. On the other hand, an increase in coffee production surrounding the Park guaranteed paid work. Deregulation of the coffee market in India and worldwide, created another uncertain institutional force that made Adivasis' livelihood capabilities more vulnerable to international coffee market fluctuations. Despite this, traditional Adivasi social relations with nearby farming communities have consistently saved the tribes during crises and emergencies. Nonetheless, even with the remunerative resources available for Adivasis to sustain their livelihoods in Kodagu, it is unfortunate that certain institutional factors outside their control are keeping Poovamma, and many others like her, in poverty. 


\section{References}

Agrawal, A. and E. Ostrom. 2001. Collective action, property rights, and decentralization in resource use in India and Nepal. Politics and Society 29: 485-514.

Agrawal, A. and K. Redford. 2009. Conservation and displacement: an overview. Conservation and Society 7: $1-10$

Ambinakudige, S. 2006. Differential impacts of commodification of agriculture in the Western Ghats of India: an extended environmental entitlement analysis. Ph.D. dissertation. Tallahassee: Florida State University.

Ambinakudige, S. 2009. The global coffee crisis and Indian farmers: the livelihood vulnerabilities of smallholders. Canadian Journal of Development Studies 28(3-4): 553-566.

Ambinakudige, S. and B.N. Sathish. 2009. Comparing tree diversity and composition in coffee farms and sacred forests in the Western Ghats of India. Biodiversity and Conservation 18: 987-1000.

Amend, S. and Amend T. 1995 National Parks without people? The South American experience. Gland, Switzerland: IUCN.

Appayya, M. K. 1999. Draft preliminary management plan for Rajiv Gandhi (Nagarahole) National Park (2000-2010). Bangalore: Karnataka Forest Department.

Bawa, K.S., J. Gladwin and S. Setty. 2007. Poverty, biodiversity and institutions in forest-agriculture ecotones in the Western Ghats and Eastern Himalaya ranges of India. Agriculture, Ecosystems \& Environment 121(3): 287-295.

Bernstein, H. 1994. Agrarian classes in capitalist development. London: Routledge.

Blaikie, P., T. Cannon. I.Davis and B.Wisner. 1994. At risk: natural hazards, people's vulnerability and disasters. London: Routledge. ( $1^{\text {st }}$ edition)

Brand, A.R. 1933. Revised working plan for a part of the tract known as the Eastern Forests of Coorg 1933 1934 to 1942-1944. Bangalore: Mysore Residency Press and Forest Department (Coorg).

Bray, D. and A.Velazquez. 2009. From displacement-based conservation to place-based conservation. Conservation and Society. 7: 11-14. http://tinyurl.com/49cz8yo

Bryant, R. 1997. The political ecology of forestry in Burma 1824-1994. Honolulu: University of Hawaii Press.

Carney, D. 1999. Approaches to sustainable livelihoods for the rural poor. London: ODI. http://tinyurl.com/4pddefo

Crawford, S., and E. Ostrom. 1995. A grammar of institutions. The American Political Science Review 89: 582-600.

De Haan, L.J. 2000. Globalization, localization and sustainable livelihood. Sociologia Ruralis 40: 339-365.

Ellis, F. 1998. Household strategies and rural livelihood diversification. The Journal of Development Studies 35: 1-38.

Freedman, E. 2002. When indigenous rights and wilderness collide: prosecution of Native Americans for using motors in Minnesota's Boundary Waters Canoe Wilderness Area. The American Indian Quarterly 26: 378-92

Glaser, B. and A. Strauss. 1967. The discovery of grounded theory. Chicago: Aldine.

Government of India. 1983. Project Tiger: 1973-1983. New Delhi: Ministry of Environment and Forests.

Greenough, P. 2003. Pathogens, pugmarks and political 'emergency': the Indian discourse on nature in the 1970s. In Greenough, P. and L. A. Tsing (eds.) Nature in the global South: environmental projects in South and Southeast Asia. North Carolina: Duke University Press. pp. 201-30.

Holloway, I. 1997. Basic concepts for qualitative research. Oxford: Wiley-Blackwell.

Holt, F.L. 2005. The catch-22 of conservation: Indigenous peoples, biologists and culture change. Human Ecology 33: 199-215.

Janara Budakattu Hakku Stapana Samithi. 2000. Nagarahole: Adivasi peoples' rights and ecodevelopment. Washington D.C.: Workshop on Indigenous Peoples, Forests and the World Bank: Policies and Practice.

Klooster, D. 2000. Institutional choice, community, and struggle: a case study of forest co-management in Mexico. World Development 28:1-20.

Kothari, A., P.Pande, S.Singh, and D.Variava. 1989. Management of National Parks and sanctuaries in India: a status report. New Delhi: Indian Institute of Public Administration.

Lele, S. and R.J. Rao. 1996. Whose co-operatives and whose produce? The case of LAMPS in Karnataka. Paper presented at National Seminar on 'Rediscovering Co-operation', Nov. 19-21. Anand, India: Institute of Rural Management. 
Langton, M.L. 2003. The 'Wild', the market, and the native: Indigenous people face new forms of global colonization. In S.Vertovec and D.Posey (eds.) Globalization, globalism, environments and environmentalism: consciousness of connections. Oxford: Oxford University Press. Pp141-167.

Langton, M.L., Z.M. Rhea and L.R. Palmer. 2005. Community-oriented protected areas for Indigenous peoples and local communities. Journal of Political Ecology 12: 23-50. http://tinyurl.com/4exyzng

Menon, S. and K. Bawa.1998. Tropical deforestation: reconciling disparities in estimates for India. Ambio 27: 576-577.

Mahanty, S. 2003. Insights from a cultural landscape: lessons from landscape history for the management of Rajiv Gandhi (Nagarahole) National Park. Conservation and Society 1: 23-47. http://tinyurl.com/4px9ao4

Peluso, N.L. 1992. Rich forests, poor people: resource control and resistance in Java. Berkeley: University of California Press.

Rangarajan. M. 1996. The politics of ecology: the debate on wildlife and people in India, 1970-95. Economic and Political Weekly 31: 2301-409.

Richter. G. 1870. Gazetteer of Coorg. Delhi: K. Publishers Distributors.

Robbins, P. 2000. The rotten institution: corruption in natural resource management. Political Geography 19: 423-443.

Ruben, D. K. 2003. People in motion: an entitlements approach to Karimojong Agro-Pastoralism. Masters thesis. Nijmegen, The Netherlands: University of Nijmegen.

Sato, J. 2000. People in between: conversion and conservation of forestlands in Thailand. Development and Change 31:155-77.

Singh, K.S. 1994. The scheduled tribes. Delhi: Oxford University Press.

Shrinidhi, A.S. and S.Lele. 2001. Forest tenure regimes in the Western Ghats: a compendium. Bangalore: Institute for Social and Economic Change.

Talbot, J. 2004. Grounds for agreement: the political economy of the coffee commodity chain. Rowman \& Littlefield.

The World Bank. 1996. India ecodevelopment project- project document. Washington DC: The World Bank. Tireman, H. 1914. Working plan for the Eastern forests of Coorg. Bangalore: Forest Department (Coorg).

Watts, M.J. 1983. Silent violence: food, famine and peasantry in Northern Nigeria. Berkeley: University of California Press.

Weber, W. 1991. Enduring peaks and changing cultures: the Sherpas and Sagarmatha (Mount Everest) National Park. In P.C. West and S.R. Brechin (eds.) Resident people and national Parks: social dilemmas and strategies in international conservation. Tucson: University of Arizona Press. Pp324331.

West, P.C., J. Igoe, and D.Brockington. 2006. Parks and peoples: the social impact of protected areas. Annual Review of Anthropology. 35: 251-277. http://tinyurl.com/64d6geh 


\begin{abstract}
Protected Areas, as a conservation strategy, often constrain livelihood outcomes of groups that are less powerful, politically marginalized, and poor. At the same time, the poor often depend on a market economy that is volatile. Working on coffee plantations and the collection of non-timber forest products (NTFPs) are the two major livelihood options available for the Adivasi indigenous community in Kodagu, India. The article identifies the institutional factors at global, regional, or local levels that influence the livelihood capabilities of Adivasis. While the creation of a National Park negatively influenced almost all aspects of the Adivasis' livelihood, labor demand on coffee farms, and NTFP collection rights outside the Park provided them with some alternative resources. But deregulation of the Indian coffee market made them more vulnerable to the market economy. The social relations between Adivasis and nearby farming communities have helped them to cope with risks to their livelihoods during crises and emergencies.
\end{abstract}

Key words: Livelihoods, Coffee, NTFP, Adivasis, LAMPS, Kodagu

\title{
Résumé
}

Les aires protégées, en tant que stratégie de conservation, entravent souvent les "livelihoods" des populations qui sont moins puissants, politiquement marginalisées, et pauvres. D'autre part, il y a une dépendance des pauvres sur une économie de marché qui est souvent volatile. Les plantations de café et la collecte de produits forestiers non-ligneux (PFNL) sont les deux options disponibles pour les communautés autochtones (Adivasis) a Kodagu, l'Inde. L'article identifie les facteurs institutionnels aux niveaux mondial, régional et local qui influent les capacités des Adivasis. Bien que la création d'un parc national avait une influence négative sur presque tous les aspects de la vie des Adivasis, la demande de main-d'œuvre agricole dans les plantations de café, et les droits de collecte des PFNL a l'extérieur du parc leur a fourni des ressources alternatives. La déréglementation du marché du café en l'Inde, cependant, créé une autre force institutionnel incertain qui les a rendus plus vulnérables à l'économie de marché. Relations sociales entre les Adivasis et à proximité des communautés agricoles les ont aidés à faire face aux risques de leurs "livelihoods" pendant les crises et les urgences.

Mots-clés: les moyens de vie, café, produits forestiers non ligneux, les Adivasis, LAMPS, Kodagu

\section{Resumen}

Las áreas protegidas, como estrategia de conservación, a menudo se limitan los medios de vida de los grupos que son menos poderosos, marginados políticamente, y los pobres. Al mismo tiempo, los pobres a menudo dependen de una economía de mercado que es volátil. De trabajo en las plantaciones de café y la recolección de productos forestales no madereros (PFNM) son las dos principales opciones de subsistencia para la comunidad adivasi indígenas en Kodagu, la India. El artículo identifica los factores institucionales en los planos mundial, regional o local, que influyen en la capacidad delos medios de vida de los adivasis. Si bien la creación de un Parque Nacional influido negativamente en casi todos los aspectos de la vida del adivasis, la demanda de trabajo en las fincas cafetaleras, y los derechos de PFNM de recolección fuera del Parque les proporcionó algunos recursos alternativos. Pero la desregulación del mercado de café de la India hizo más vulnerable a la economía de mercado. Las relaciones sociales entre los adivasis y cerca de las comunidades agrícolas han contribuido a hacer frente a los riesgos para sus medios de subsistencia en situaciones de crisis y emergencias.

Palabras clave: medios de vida, café, PFNM, los adivasis, LAMPS, Kodagu 